\section{UTVALGT ARBEIDSSTED}

\section{Helse Fonna}

I Helse Fonna er du ein del av eit godt fagmiljø der du sjølv kan vere med å påverke utviklinga.

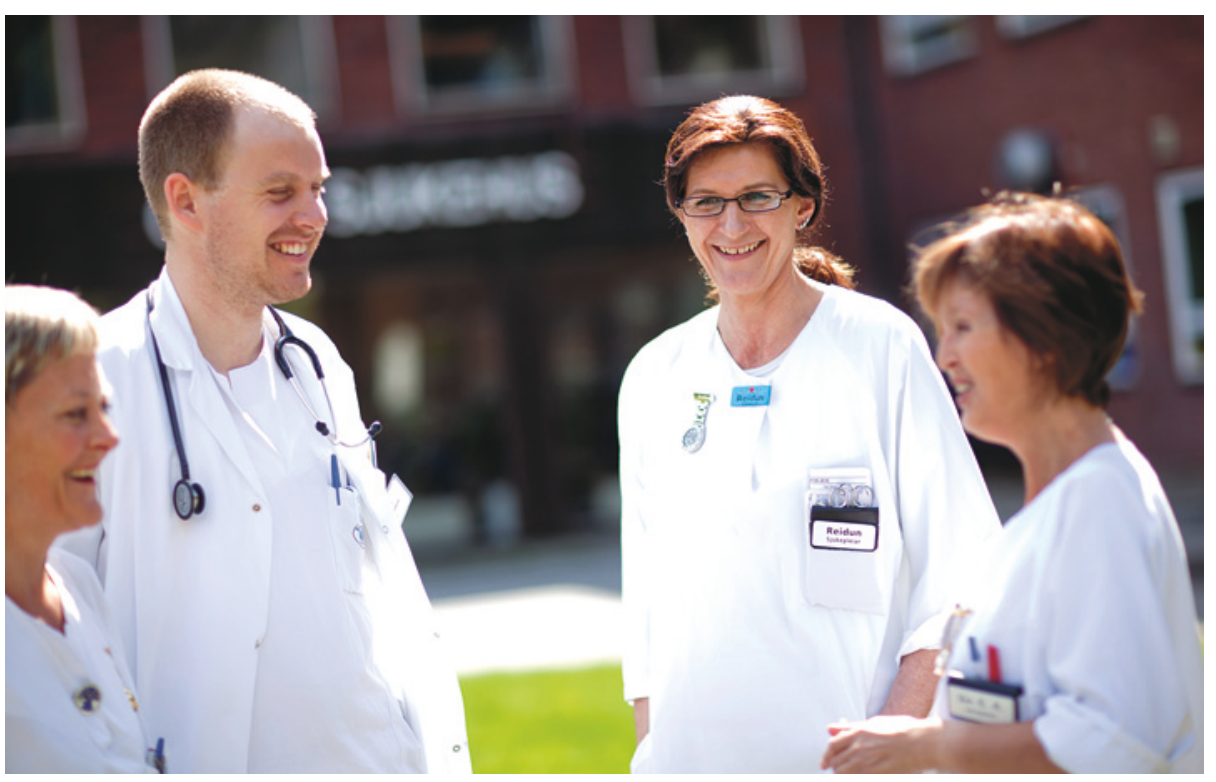

Fornøyde kolleger ved Helse Fonna. Foto: Haakon Nordvik/Helse Fonna

Helseføretaket består av Valen psykiatriske sjukehus og dei somatiske sjukehusa i Haugesund, Odda og Stord, i tillegg til fire distriktspsykiatriske sentra: Folgefonn, Haugaland, Karmøy og Stord DPS. Det er nært samarbeid mellom sjukehusa og moglegheit for frivillig ambulering og rotasjon. Føretaket er godt dekka med spesialistar og greinspesialistar innan dei fleste område. Det er gode ordningar for at legane skal kunne auke og vedlikehalde sin kompetanse. Helse Fonna har nært samarbeid med universitetssjukehusa i Stavanger og Bergen. Haugesund sjukehus har utplasserte medisinstudentar frå Universitetet i Bergen.

\section{Forsking}

Forskingskompetansen er i sterk auke, både gjennom utdanning og ved tilsettingar. Det fins moglegheiter for forskingsstipend, anten til delvis frikjøp av tid eller til forskingspermisjonar. Helseføretaket har òg oppretta enkelte deltidsstillingar som forskar for tilsette i klinisk hovudstilling. Dette er stillingar på doktorgrads- og postdoktornivå, som skal føre til auke i forskingsaktiviteten. Det fins aukande grad av rettleiarkompetanse og erfaring med å bygge nettverk til større forskingsmiljø.

\section{Variert region}

Våre 3900 tilsette gir spesialisthelsetenester til ei befolkning på 170 500, fordelt på 19 kommunar. Helse Fonna-regionen er mangfaldig og kan tilby det meste: eit eldorado for friluftsinteresserte, byliv, festivalar og god kommunikasjon innalands og til utlandet. Vi har gode ordningar for våre tilsette, som velferdslag og tenestebustadar ved alle våre sjukehus, og arbeider kontinuerleg med å vidareutvikle eit godt arbeidsmiljø.

Mer informasjon om Helse Fonna finn du på www.helse-fonna.no.

\section{www.legejobber.no}

27.10.

FRIST FOR REGISTRERING AV ANNONSER TIL NR. 21/2014 PÅ LEGEJOBBER.NO

\section{Om Legejobber.no}

Legejobber.no er Tidsskriftets stillingsportal for leger og for stillingsannonsører.

Som annonsør kan du nå bestille annonsen døgnet rundt via Legejobber.no. Du registrerer nettannonsen og papirannonsen samtidig.

Som jobbsøker kan du på Legejobber.no enkelt søke etter ledige jobber etter spesialitet. geografisk område eller i fritekst.

Ønsker du å motta varsel om ledige stillinger innenfor et bestemt område?

På Legejobber.no kan du abonnere på ledige stillinger.

\section{Priser på stillingsannonser 2014}

* Gjelder for kombinasjon papir/nett.

Format

$1 / 1$ side

Størrelse

Pris svart-hvitt

$185 \times 245$

Pris svart-hvitt

31600

34700

$1 / 2$ s. liggende

$185 \times 112$

Pris svart-hvitt

17000

Pris 4 farger

20000

1/2 s. stående

$90 \times 245$

Pris svart-hvitt

17000

Pris 4 farger

20000

$1 / 4$ side

Pris svart-hvitt

$90 \times 112$

Pris 4 farger

$1 / 8$ side

9000

11000

$90 \times 45$

Pris svart-hvitt

6100

7100 